Rapid Reviews COVID-19

\title{
Reviews of "Inhibition of \\ SARS-CoV-2 infection in \\ human cardiomyocytes by \\ targeting the Sigma-1 \\ receptor disrupts \\ cytoskeleton architecture \\ and contractility"
}

Carmen Abate ${ }^{1}$, Kenji Hashimoto ${ }^{2}$

${ }^{1}$ Università degli Studi di Bari, ${ }^{2}$ Chiba University: Chiba Daigaku, Clinical Neuroscience, Japan

Published on: Mar 29, 2021

License: Creative Commons Attribution 4.0 International License (CC-BY 4.0). 
To read the original manuscript, click the link above.

Summary of Reviews: This preprint uses iPS-derived cardiomyocytes to investigate the role of Sigma-1 Receptor (S1R) during SARS-CoV-2 infection and finds $S 1 R$ antagonism reduces $S A R S-C o V-2$ replication at the expense of cardiomyocyte function. Reviewers deem these claims reliable.

\section{Reviewer 1 (Carmen Abate) | प्र०ण}

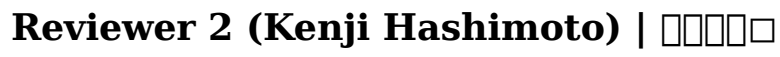

$$
\begin{aligned}
& \text { RR:C19 Strength of Evidence Scale Key. } \\
& \text { प्रमप = Misleading } \\
& \text { प्र००० = Not Informative } \\
& \text { प्रा पि = Potentially Informative }
\end{aligned}
$$

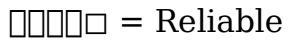

$$
\begin{aligned}
& \text { प्राप्र = Strong }
\end{aligned}
$$

To read the reviews, click the links below. 